\title{
Features of the Work of Industrial Fences in the Conditions of the Far North and Analysis of Technologies for Strengthening Existing
}

\author{
Alexander Grigoriev \\ Institute of Engineering Sciences \\ Pskov State University \\ Pskov, Russia \\ grigorevalexandr@mail.ru \\ Nadezhda Dmitrieva \\ Institute of Engineering Sciences \\ Pskov State University \\ Pskov, Russia \\ tom-cat28@ya.ru
}

\author{
Alexander Rytvin \\ Institute of Engineering Sciences \\ Pskov State University \\ Pskov, Russia \\ ry.work@mail.ru \\ Elena Strelnikova \\ Institute of Engineering Sciences \\ Pskov State University \\ Pskov, Russia \\ strelnikova-164@mail.ru
}

\author{
Melkov Boris \\ Institute of Engineering Sciences \\ Pskov State University \\ Pskov, Russia \\ bormssp@bk.ru
}

\begin{abstract}
The paper focuses on the work of steel industrial fences in the conditions of the Far North, based on the results of the actual impact of snow masses. A computational model is developed for estimating the resulting stresses in the structure. Methods for assessing the impact of snow masses are proposed. The technologies of strengthening the existing fences are analyzed.
\end{abstract}

Keywords - industrial fences, snow loads, technology of reinforcement of industrial fences

\section{INTRODUCTION}

The article describes the features of the work of industrial fences of the Glitter3d type, produced in the form of a welded grating made of a steel bar with a diameter of 3-5 mm with a polymer shell. Fences of this type are used everywhere for the construction of fences of various objects. The peculiarity of this fence is the ability to maintain visual transparency without losing its main functional purpose. Such fences can be used for fencing school yards, warehouses, military and industrial facilities. They are often installed on the borders of land plots of railway stations and bus stations, sports grounds and house territories, parks, gardens, squares. This type of fencing is particularly widely used in the construction of protective fences of protected areas and objects. Due to the transparency, grating fences ensure timely detection of the intruder near the protected object.
The use of industrial fences is now widespread on the territory of the Russian Federation. Fences are widely used in various climatic latitudes. However, when using industrial fences in latitudes with a high height of snow cover, frequent destruction of the grids of this fence was repeatedly noted.

In 2019, the authors of the article conducted a technical survey of more than 30 kilometers of such a fence located in the area of the Kola Peninsula, near the city of Murmansk. During the survey, numerous damage to the grating nets was revealed. Due to the large length of the fence examined, it became possible to systematize the defects and damages that occur in them in the conditions of the Far North.

\section{CLIMATIC CONDITIONS}

The climate of the area where the survey of fences was carried out is formed under the influence of Arctic and warm Atlantic air masses.

Natural and climatic conditions are characterized by long and cold winters with strong winds, a lack of natural light and ultraviolet radiation, the spread of permafrost, and high humidity. Murmansk belongs to the AtlanticArctic zone of temperate climate with a predominance of warm air flows from the North Atlantic and cold air flows from the Atlantic sector of the Arctic, which is characterized by an increase in the frequency of cyclones in the cold season and anticyclones in the warm season. 
The proximity of the warm Gulf Stream causes abnormally high winter air temperatures here, large temperature differences between the Barents Sea and the mainland in the summer and winter months - large temperature variability when the wind direction changes.

According to the schematic map of climate zoning (SP 131.13330.2012), the construction area belongs to the construction and climate zone IIA. According to the schematic map of the zoning of the northern construction and climate zone (SP 131.13330.2012, fig. A2) the territory is characterized by the least severe conditions.

The average temperature of the coldest winter months (January, February) is $-9^{\circ} \mathrm{C}$ on the coast of the Kola Bay. The average temperature of the warmest month (July) ranges from $+10^{\circ} \mathrm{C}$ to $+14^{\circ} \mathrm{C}$. The duration of the frostfree period on the coasts exceeds 100 days, in other areas it ranges from 50 to 100 days.

Murmansk completely belongs to the area of excessive moisture. The annual precipitation reaches $600-700 \mathrm{~mm}$ (on the coast of the Kola Bay). The height of the snow cover varies from $80 \mathrm{~cm}$ in the south to $40 \mathrm{~cm}$ or less on the coast of the Kola Bay, where the snow is blown away by the wind.

Frequent snowstorms are typical for the city of Murmansk. The largest number of them falls on the period from January to March.

The Polar night lasts from December 2 to January 12, and December 22 is its peak. In the period from May 22 to July 22, the sun does not go below the horizon, the polar day comes.

Storms are most frequent (the average annual number of days - 70 - 90) from October to March, fog and precipitation - in July - August. Poor visibility (less than 1 mile) can be observed throughout the year, its frequency is 5-15\%.

Frequent and abrupt changes in weather conditions sometimes lead to heavy snowfall with the formation of snow drifts on the roads (with an average daily precipitation rate of about $40 \mathrm{~cm}$ ), storm winds (with a wind force of $25 \mathrm{~m} / \mathrm{s}$. and more), severe frosts (with a temperature of- $25-30^{\circ} \mathrm{C}$ ), ice on the roads, icing of power lines.

In accordance with SP 20.13330.2016 "Loads and impacts. Updated version of $\mathrm{SNiP} 2.01 .07-85$, *” the territory belongs to:

- to the IV wind region, the standard wind pressure is $0.48 \mathrm{kPa}(48 \mathrm{kgf} / \mathrm{m} 2)$;

- to the II district by the thickness of the ice wall, the thickness of the ice wall is $5 \mathrm{~mm}$;

- by the weight of the snow cover to the $\mathrm{V}$ district with the calculated value of the weight of the snow cover-350 $\mathrm{kgf} / \mathrm{m} 2$.

According to SP 14.13330.2018 and OSR-97, the seismicity of the area is 6 points.

According to V. Demin and F. Romanenko, the climate has been warming recently, but precipitation is also increasing [1] - [4].

\section{RESULTS OF THE FENCE SURVEY AND DAMAGE CLASSIFICATION}

The fence is a metal grating welded at the crosshairs of the rods. The rods are coated with a polymer shell or paint. The supporting elements are metal racks with a cross section of $50 \times 50 \times 2$ or $80 \times 80 \times 2$ millimeters.

The appearance of the section is shown in Fig. 1. The main damage to the sections is structured according to the frequency of their occurrence and is shown in the following figures:

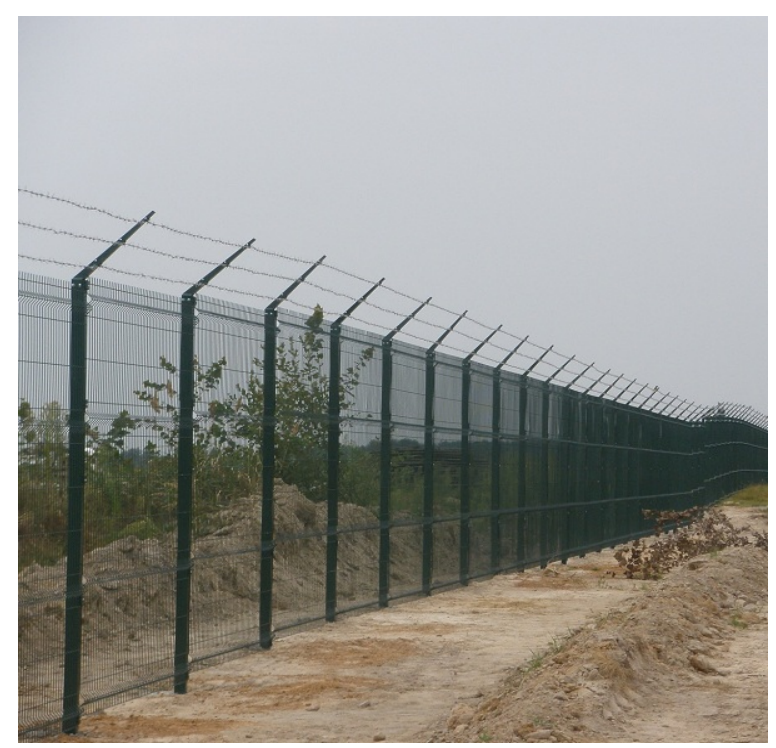

Fig. 1. View of an undamaged grating fence.

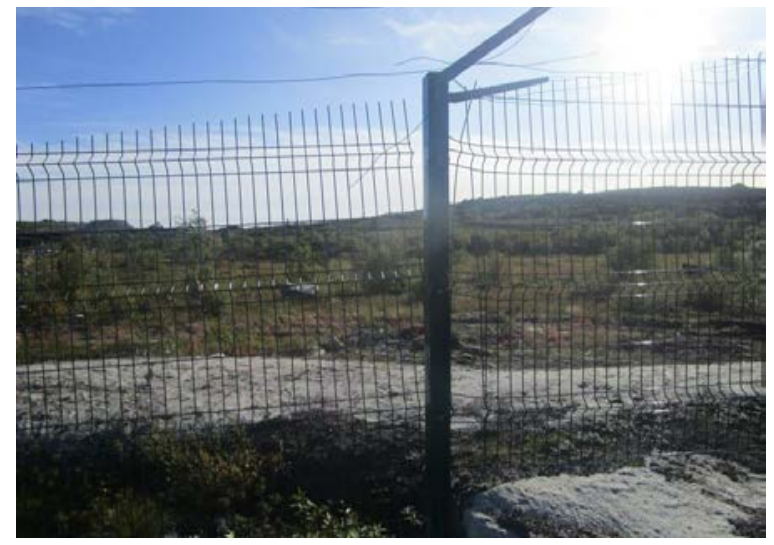

Fig. 2. Destruction of the panel near to the support. 
Environment. Technology. Resources. Rezekne, Latvia Proceedings of the $13^{\text {th }}$ International Scientific and Practical Conference. Volume 3, 84-88

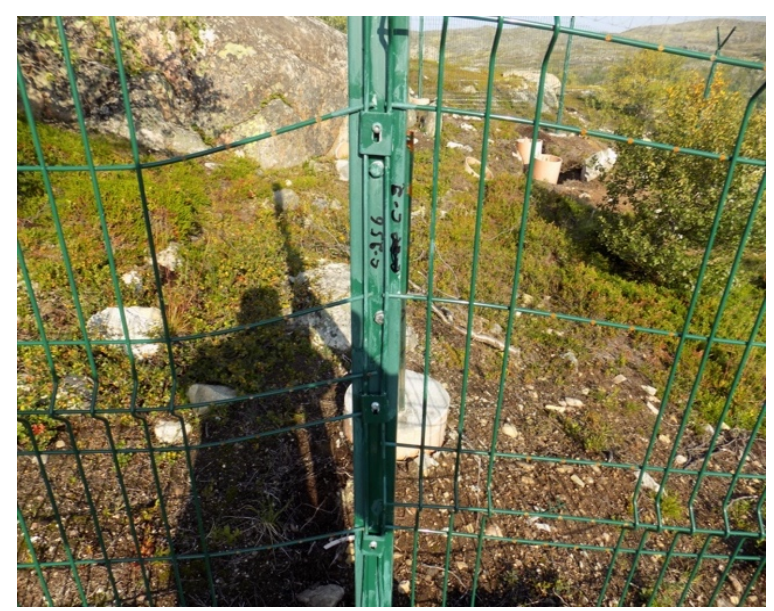

Fig. 3. Destruction of the panel near to the support.

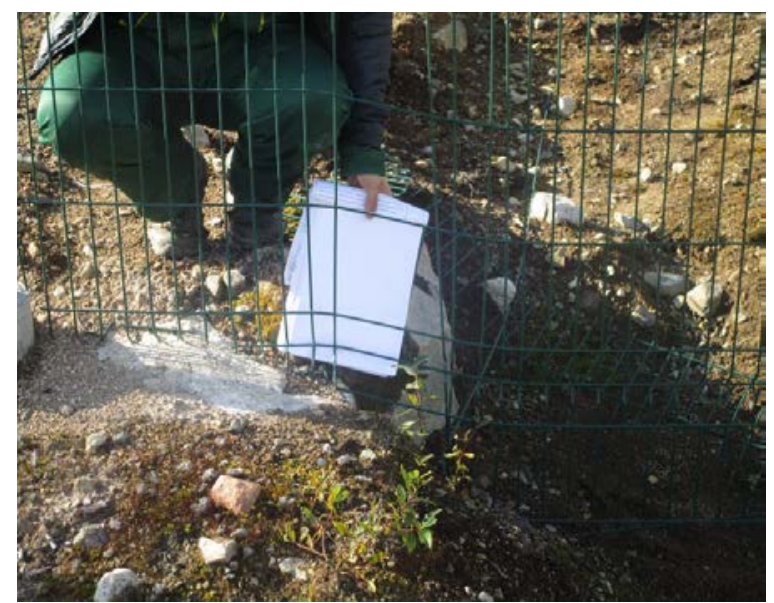

Fig. 4. Destruction of the panel between the supports.

The most common defect of the panels is the destruction of the welded joints near the supports with the bending of the panels. Next in frequency is damage with the grid bending out of the plane. There are also such destructions as a cut of bolts of fastenings, loss of stability of support posts, but all these damages make no more than 10 percent, and are manifested together with damage to welded joints near supports with bending of panels. Damage to the panels is significant for the fence as a whole. To determine the causes of destruction, it is necessary to analyze the causes that led to the occurrence of these damages.

\section{ANALYSIS OF THE CAUSES OF DEFECTS}

After analyzing the nature of the damage to the fences, taking into account their localization along its length, the complex terrain where the fences are located, and the difficult climatic and meteorological conditions of the construction area, it can be concluded that all the abovementioned defects appeared due to the impact on the fence of increased snow deposits that occur around it and which, apparently, are characteristic of this type of terrain. In accordance with SP 20.13330.2016 "Loads and impacts. Updated version of SNiP 2.01.07-85, *” construction territory refers to:
- to the IV wind region, the standard wind pressure $48 \mathrm{kgf} / \mathrm{m} 2$;

- to the II district by the thickness of the ice wall; the thickness of the ice wall is $5 \mathrm{~mm}$;

- to the $\mathrm{V}$ snow area, the estimated weight of the snow cover is $350 \mathrm{kgf} / \mathrm{m} 2$.

The estimated value of the snow cover weight according to the normative data for this area is only 350 $\mathrm{kgf} / \mathrm{m} 2$ (250 $\mathrm{kgf} / \mathrm{m} 2$ is the normative value), but it is obvious that the actual snow loads in the area where the fences are located are much higher.

Snowfall and snowstorms in winter due to the difficult terrain lead to increased snow deposits, especially at the foot of the slopes, in the lowlands and in the beds of streams, forming snow drift of different heights and different lengths.

In order to analyze what happens in the winter period with the built fence, we will use information taken from open sources, including data from manufacturers of similar fence systems.

Let us consider the freely available photos taken in the winter of 2016-2017 clearly illustrating the amount of snow deposits (Fig. 5).

On the one hand, fences can be completely covered with snow at its entire height. The thickness of the snow cover in this case can reach 2-2.5 m, and in the presence of a protective safety barrier and large values. The density and thickness of the snow layer is such that it can withstand the weight of a person (Fig. 5).

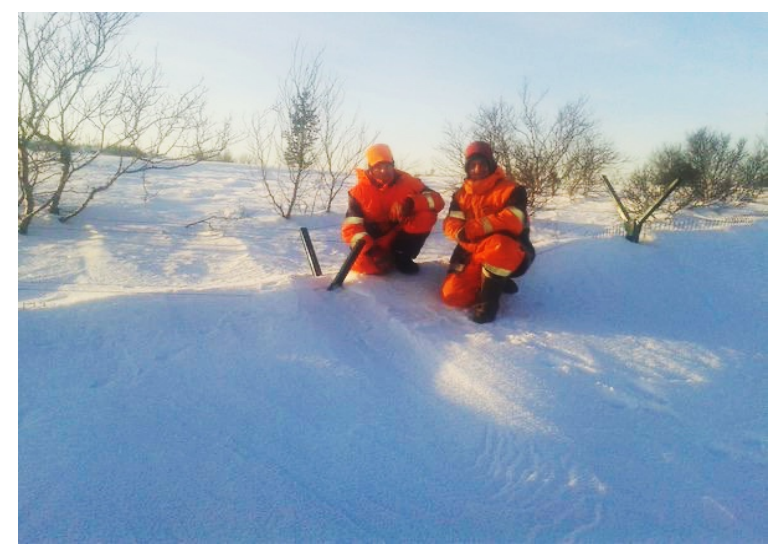

Fig. 5. The height of the snow next to the fence.

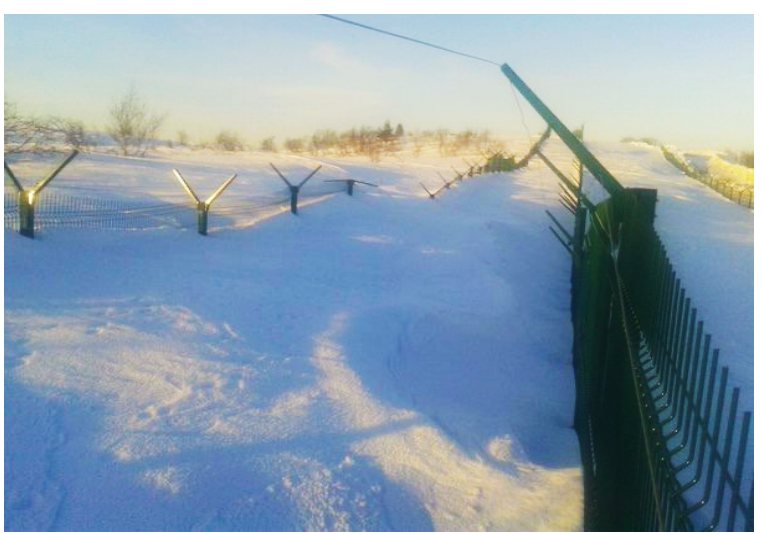

Fig. 6. Snow cover height. 
On the other hand, in winter, the elements of fences become icy, snow freezes on them, gradually turning the mesh panel into a vertical surface that is almost impervious to wind and snow. In this state, the fences practically begin to perform a snow-retaining function, for which they were not designed.

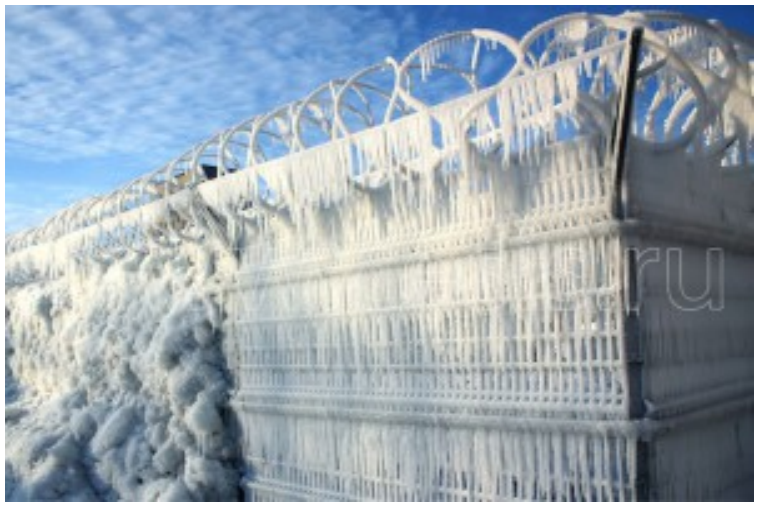

Fig. 7. Snow cover height.

Snowfalls and blizzards lead to increased snow deposits at the icy fences, forming snow drifts - snow bags. The height of snow bags can reach values commensurate with the height of the fence. At the same time, the snow bag is formed in two directions, but on the windward side its value is greater.

Snow deposits are formed in layers. With temperature changes and wind action, the snow gradually cures and increases its density. In the lower layers, during thaws, meltwater can appear, which, when absorbed into the snow, significantly increase its mass, and when frozen, the snow mass saturated with water can turn into ice.

Next, we will show how much the value of the snow load can differ from the standard value for the $\mathrm{V}$ snow area during the formation of snow drifts.

Let us estimate the amount of snow load on the earth's surface from the accumulated snow cover with a thickness of $2-2.5 \mathrm{~m}$.

According to clause 5.3 of GOST R 53613-2009 “The impact of natural external conditions on technical products. General characteristics. Precipitation and wind”, the density of the accumulated snow varies from 200 to $400 \mathrm{~kg} / \mathrm{m} 3$.

Then the snow load from the snow cover with a capacity of $2-2.5 \mathrm{~m}$ on the ground surface will be:

$2 \cdot 200=400 \mathrm{~kg} / \mathrm{m}^{2} ; 2 \cdot 400=800 \mathrm{~kg} / \mathrm{m}^{2}$;

$2.5 \cdot 200=500 \mathrm{~kg} / \mathrm{m}^{2} ; 2.5 \cdot 400=1000 \mathrm{~kg} / \mathrm{m}^{2}$,

$400-1000 \mathrm{~kg} / \mathrm{m}^{2}$, which is $1.6-4$ times higher than the standard value for the $\mathrm{V}$ snow area of $250 \mathrm{~kg} / \mathrm{m}^{2}$.

Let us estimate the amount of snow load when a snow bag is formed at a fence with a height of $2 \mathrm{~m}$ and $2.5 \mathrm{~m}$.

The assessment is performed using the program of the WEST engineering and calculation complex "SCAD OFFICE" in accordance with the requirements of clause 10 of SP 20.13330.2016 "Loads and impacts. Updated version of SNiP 2.01.07-85*”. According to the results of the calculation, it turns out that the snow load in the area of the formation of a snowbank at the fence exceeds the standard value for the $\mathrm{V}$ snow area equal to $250 \mathrm{~kg} / \mathrm{m}^{2}$ by 1.3 - 1.6 times (Fig. 8).

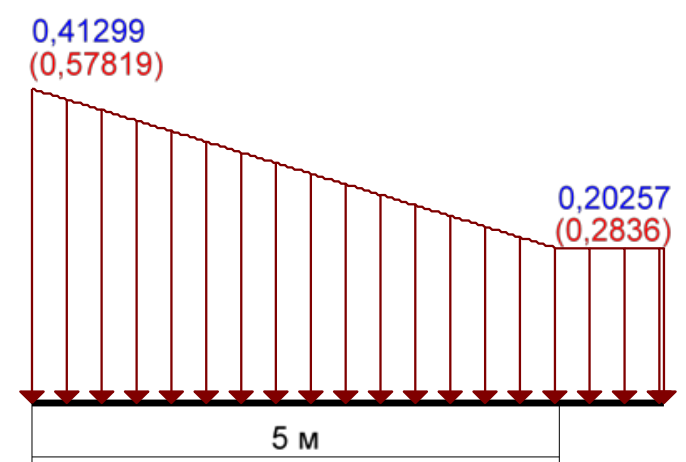

Fig 8. Calculation result snow load.

Snow and ice masses formed at the panels in winter, when freezing and subsequent thawing leads to deformation of the panels and further to their damage in the form of destruction of welded joints between the grid rods. When the welded joints between the mesh rods are destroyed, the rigidity of the panel decreases, causing even greater deformations, which in turn lead to even greater damage to it. Eventually, the panel breaks out of the mounts on the racks.

Freezing and subsequent melting of snow and ice masses also leads to damage to the fence elements.

Damage to panels and elements of protective barriers can occur both during one winter period (for one year), and gradually over several years. Since damage to fences leads to violations of the protective perimeter and to expensive repairs to replace fences, it is necessary to develop measures for the construction of fences that resist such snow loads [4] - [5]. Fences of this type are used throughout the Russian Federation and it should be noted that the fences which are regularly cleaned of snow do not experience such damage.

\section{MEASURES THAT INCREASE THE OPERATIONAL PROPERTIES OF FENCES}

To reduce the impact of meteorological influences (primarily snow) on the elements of fences, two groups of measures can be distinguished: constructive and operational.

Structural measures (for strengthening fences) should include the installation of 2 - 3 horizontal elements between the posts at a height - crossbars made of bent or closed galvanized profiles, to which additional fastening of the panels is carried out with retainers.

An example of a reinforced similar fence and its elements are shown in Fig. 9 and 10 (technical solution of JSC "CeSIS NIKIRET», http://www.cesis.ru/ zagrazhdenie-maxaon-arktika). 


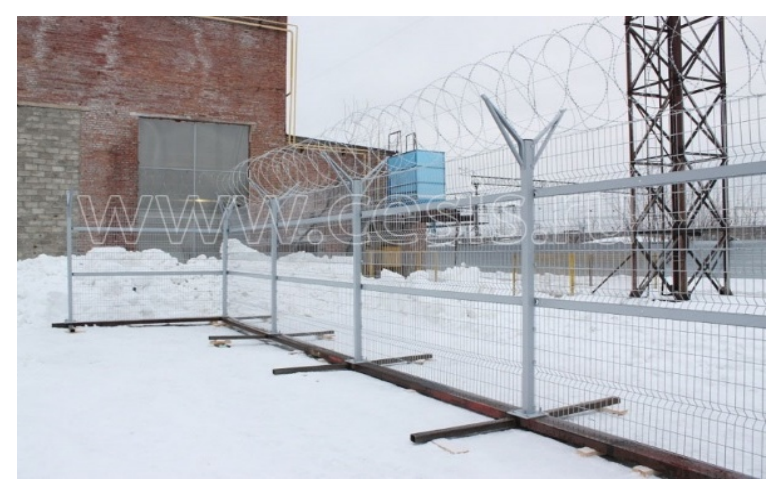

Fig. 9. An example of a reinforced similar fence, an additional stiffener, a reinforced tip (taken from the site http://www.cesis.ru)

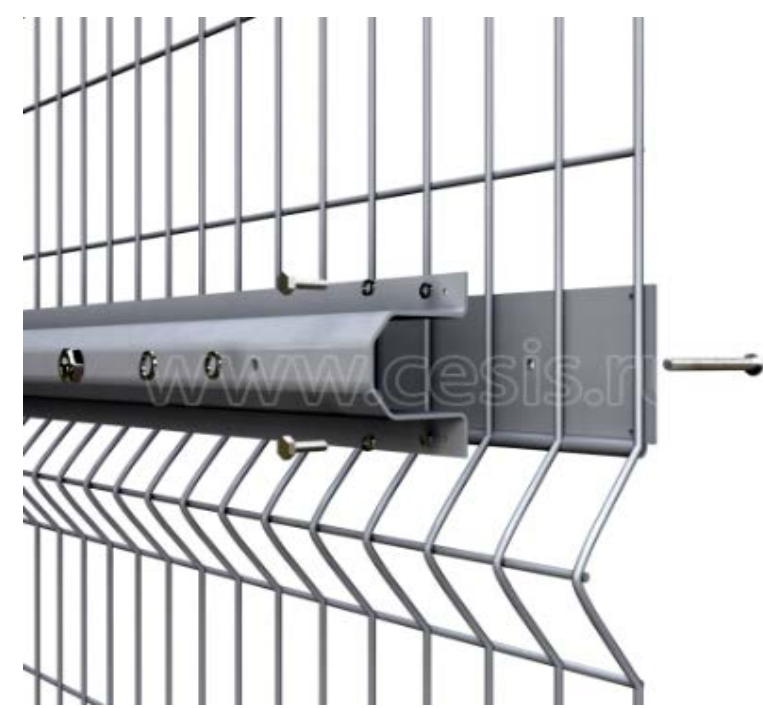

Fig. 10. Additional stiffener (taken from the site http://www.cesis.ru)

Operational measures should include:

- regular snow removal between the fences and in front of them, thereby preventing the accumulation of snow masses and the formation of huge snow drifts at the fences;

- cleaning of fence panels from frozen snow.

Snow removal is also recommended during the construction period.

\section{CONCLUSION}

According to the results of the study of the grating fences features in the conditions of the Far North, it was determined that the existing technology of the device of fences needs to be improved. Fences around which snow removal will be periodically carried out do not need to be finalized. For the rest of the installed or projected fences of this type, it is recommended that the fences be made with additional horizontal elements that ensure the rigidity of the panels.
When using horizontal crossbars between the risers, a structure is formed in which the panels cease to be loadbearing elements and perform only an enclosing function.

In conclusion, it should be noted that the existing standards of the Russian Federation do not have instructions for determining the snow load on such panels, which makes it difficult to calculate such structures. According to the results of the inspection of the actually mounted panels, it was determined that the fence panels work as beams taking on the snow load. The deformation and destruction of the panels look like a beam with a rigid pinching on the supports.

Based on the results of this work, it is recommended to conduct experiments with a real assessment of the snow load on the fence panel. According to the results of the survey, it was determined that a significant part of the snow load can be transmitted directly to the fence panels, and not to the ground surface.

\section{REFERENCES}

[1] F. Romanenko, "Geomorphological processes in the mountains of the Kola Peninsula and climate change," Bulletin of Moscow University, Moscow, № 5, pp. 78-86, 2016. (in Russian)

[2] V. Diomin, A. Antsiferova, and O. Mokrotovarova, "Changes of the air temperature in Murmansk since the 19th century," Bulletin of Kola Scientific Center RAN, Murmansk, № 1, pp. 113-125, 2015. (in Russian)

[3] A. Fedyaev, "Development of methods for calculating the probabilistic characteristics of snow loads for assessing the reliability of building structures," Bulletin of Scientific Conferences, Tambov, № 12-2, pp. 106-108, 2016. (in Russian)

[4] A. Chapligin and N. Fedorov, "Protective fences. Problems and prospects of application," Security Algorithm, Saint Petersburg, № 4, pp. 50-53, 2016. (in Russian)

[5] I. Vasilyev, "Modular temporary fencing and stationary objects," Oil and Gas Exposition, Penza, № 4, p. 82, 2014. (in Russian)

[6] N. Kazakov, A. Muzichenko, E. Kazakova, I. Kononov, and V. Pavlov "The structure and texture of the snow mass on the Kola Peninsula," Snow Physics, Chemistry, and Mechanics, YuzhnoSakhalinsk, part 1, pp. 58-63, 2017. (in Russian)

[7] SP 20.13330.2016 "Loads and impacts. Updated version of SNiP 2.01.07-85* (with Amendments N 1, 2)"

[8] SP 131.13330.2018 "SNiP 23-01-99* Construction Climatology"

[9] GOST R 57278-2016 "Protective fences. Classification. General provisions"

[10] GOST R 53613-2009. "The impact of natural external conditions on technical products. General characteristics. Precipitation and wind"

[11] SP 16.13330.2017 "Steel structures. Updated version of SNiP II23-81*" (as amended, with Amendments N 1, 2)

[12] T. Ohlopkova, G. Guryanov, A. Plotnikov, "Construction and design of buildings and structures in permafrost conditions," Engineering Bulletin of the Don, №4, 2018. (in Russian)

[13] M. Kasperski, "A consistent approach for estimating the design value of the snow load on the ground from confined ensembles," in Proc. of 7th Int. Conf. on Snow Engineering, 2012, Fukui, Japan.

[14] M. Kovalev, "New Fensys developments for GAZPROM Group facilities," Oil and Gas Exposition, p. 73, 2013. (in Russian). 